\title{
Federalism as an Instrument for Unity and the Protection of Minorities: A Comparative Overview: Ethiopia, India and the US
}

\section{Abstract}

Legesse Tigabu Mengie*

Accommodation of differences is used by federal systems to hold their units together. Lack of accommodation of diversity could lead to conflicts and pose danger for a union, particularly, in multicultural federal systems like Ethiopia. This article explores the protection of diverse groups and preservation of a union in federal systems. It involves a comparative overview of three jurisdictions: Ethiopia, India and the US. Although comprehensive discussion on the relevant principles of federalism across these federal systems cannot be done in a single article, an investigation into the three jurisdictions gives insight as these jurisdictions demonstrate substantially different federal features while they share some of the hallmarks of federalism. The US represents a territorial federal system. Indian federation is multicultural with unique centripetal tendencies and this would make it a quasi-federal system. The Ethiopian federal system, on the other hand, appears to empower ethnic groups by making them its building blocks. This article examines the accommodation of diversity and protection of minorities in such differently designed federal systems and aims at drawing relevant lessons.

\section{Key terms}

Federalism, unity, representation of minorities, ethnic federalism DOI http://dx.doi.org/10.4314/mlr.v10i2.1

\section{Introduction}

Unity, regional autonomy, protection of minorities, conflict management and establishment of a civilized and democratic community are among the most important issues in many countries. Federalism is a form of government structure which can address such concerns. While a unitary form of government may erode regional autonomy, confederations may encounter problems in building a lasting union.

\footnotetext{
* Legesse Tigabu Mengie, LL. B (Haramaya University), LL.M in Comparative Constitutional Law (Central European University), LL.M in International and European Public Law (Erasmus University), Senior Lecturer in Law, College of Law and Governance, Jimma University; Email: <legessetigabu@yahoo.com> or $<$ legeselaw@gmail.com>
} 
Various comparative studies on different aspects of federalism have mostly focused on territorial federal systems. This is, partly, because most of the developed federal systems, which are considered as models, are territorial. Thomas Hueglin and Alan Fenna have, for example, contributed a comparative work on federalism from the perspective of democratic governance involving, primarily, territorial federal systems including the US, Canada, Germany, Australia and Switzerland. ${ }^{1}$ Michael Burgess uses such federal systems to make a distinction between federalism and other forms of governance. ${ }^{2}$

In his comprehensive work on comparative federalism, 'Comparing Federal Systems', Ronald Watts compares 25 federal systems. ${ }^{3}$ His work involves territorial and non-territorial federal systems. However, this work gives emphasis to territorial federal systems, and does not provide detailed analysis on non-territorial federal systems like Ethiopia. We cannot expect such details as his work involves almost all federations.

Assefa Fiseha compares differently designed -territorial and non-territorialfederal systems from the perspective of accommodation of 'ethno-linguistic groups' and division of legislative, executive and judicial powers. ${ }^{4}$ The Forum of Federations, an international organization based in Canada, has also initiated comparative studies on federalism involving both territorial and non-territorial federal systems. Most of these studies emphasize on fiscal federalism, policy making in federations, conflict management and decentralization of power.

This article builds on these works with a particular focus on the preservation of unity and the protection of minorities by comparing differently designed federal systems and incorporating new developments particularly in Ethiopia. The focus of the article is on the role of federalism in preserving unity and protecting the interests of minorities. These federations are designed differently and their federal features can be used as inputs to draw lessons for federal systems. The brief investigation into the ethnic based federal system in Ethiopia, the formally centralized quasi-federal system in India and the territorial federal system in the US is meant to give an overview on the role of different forms of federalism in preserving unity and accommodating diverse interests.

The first two sections of the article present theoretical aspects of federalism, unity, diversity and the protection of minorities. The third section explores representativeness of shared federal institutions. The fourth section highlights

${ }^{1}$ Thomas Hueglin and Alan Fenna (2006), Comparative Federalism: A Systematic Inquiry, University of Toronto Press, p. 1.

${ }^{2}$ Michael Burgess (2006), Comparative Federalism: Theory and Practice, Routledge, pp. 82-99.

${ }^{3}$ Ronald Watts (2008), Comparing Federal Systems, Queens University Press, p. 1.

${ }^{4}$ Assefa Fiseha (2006), Federalism and the Accommodation of Diversity in Ethiopia: A Comparative Study, Wolf Legal, pp. 2-14. 
the main factors which may lead to disintegration of a federal system. Section 5 explores constitutional adjudication and the protection of the rights of minorities and preservation of unity.

\section{Federalism as the Synthesis of Unity and Diversity}

\subsection{Federalism}

As federalism ${ }^{5}$ is basically a political arrangement, each federal system has its own unique nature which is shaped by long historical, political, social and economic factors. Malcolm M. Feeley states that "a political entity that is governed by a single central government making all significant decisions cannot be described as federal entity without abandoning the ordinary meaning of the term." He added that "the same is true for a group of separate political entities that have entered into an alliance that precludes conflict among them but leaves all other decisions under the control of the separate political entities." 7

If all basic decisions are made by the central political entity, the existence of constituent units does not make the system federal; rather it is simply a decentralized form of government. Under such settings, the units are subjects of the central political entity. This would mean that their power, if any, is given and can be taken away by the central government at any time as they are formed by and subjects of the central entity. ${ }^{8}$

A federal system is also different from other forms of association like confederation. Such forms of arrangement give total sovereignty for the units and they subordinate the central political entity to the constituent units. The federal system is somewhere in between. Both the central and constituent units under a federal system have constitutionally guaranteed autonomous power and thus one is not the subject of the other. ${ }^{9}$ Both are established by a constitution which is neither under the monopoly of the central nor constituent political entities and both have independent legitimate power which enables them to act on people directly. ${ }^{10}$

\footnotetext{
${ }^{5}$ Malcolm M. Feeley and Edward Rubin (2008), Federalism, political identity and tragic compromise, the University of Michigan Press, p.7. In this book, Malcolm M. Feeley and Edward Rubin have explained federalism and related concepts like political identity under chapter one. They have also gone through related but different concepts like decentralized forms of government, consociation and democracy which need to be distinguished from federalism.

${ }^{6}$ Ibid.

${ }^{7}$ Ibid.

8 Ronald Watts (1999), Comparing Federal Systems, $2^{\text {nd }}$ ed, Queen's University Press, pp.943-945.

9 Daniel Elazar (1987), Exploring Federalism, University of Alabama Press, 2-7.

${ }^{10}$ Ibid.
} 


\subsection{Federalism, unity and diversity}

In countries where multi-ethnic, multi-linguistic and multi-cultural societies have survived upon the failure of attempted assimilation processes, territorial federalism and individual liberalism may not function well. On the one hand, an attempt of high scale assimilation in the contemporary world may not be realized without violating fundamental rights. Instead, there may be gradual and voluntary assimilation through economic integration. But this cannot be attained easily as it is indeed a challenge to bring about substantial and inclusive economic changes and integration to the benefit of the general public.

Integration usually takes a long time because individuals in pre-assimilated societies are shaped by their ethnic, linguistic or cultural groups and give value for these elements in their identity. While individual liberalism opts to leave the individual free to choose among values, communalism gives emphasis to ethnic/linguistic/cultural group identities. We can indeed recognize and promote all identities and at the same time respect individual rights.

One may argue that ethnic federalism -the Ethiopian model- is not a feasible way to preserve unity in diversity as this would exaggerate the differences and lead to conflicts. Such views may give preference to other ways through which identity issues can be addressed as will be explained in the subsequent sections. Specifics in any federal system will differ based on previous political, historical, social and economic factors. But, the basic goal in all federal systems is to keep unity while addressing diverse interests.

In the course of striking the balance between the forces of unity and diversity, rendering the center too strong can lead to conflict and threaten unity. The other extreme of unduly strong centrifugal forces may allow the regional sates to leave the federation easily and thus impede unity. Therefore, a wisely framed federation has to provide the right balance between these tensions. The shift from confederation to a federal form of government in the US was, for instance, to avoid problems associated with a weak central political entity.

While some federal systems have constitutional mechanisms to make federal laws and decisions supreme over regional ones, such supremacy is reflected through practice in Ethiopia. If the Ethiopian regional states become strong and conflict arises in blurred areas of power in the future, there is no constitutional provision which can help us determine the decision that has to prevail. Even though the FDRE Constitution prevails over all federal and state laws and decisions (Art 9), the Constitution has not made other federal laws and decisions supreme over the regional ones. Considering the basic goals and principles of federalism, the FDRE Constitution may be interpreted as giving slight supremacy for the federal government.

The Indian federation on the other hand is designed with a strong central government in mind and this is because of high economic and industrial 
disparities between regions which lead to continuous conflicts threatening the union. ${ }^{11}$ In the US, the supremacy clause under Art VI has proclaimed the supremacy of the federal government if there is conflict between the federal and state laws. ${ }^{12}$ Conflict of laws does not refer to cases where one level of government encroaches into the power of the other to make a law. If this happens, the law is void and there is no conflict. The supremacy clause rather comes to play to solve conflict of laws that arise where the two levels of government in a federation are acting within their legitimate power.

\section{Federalism and the Protection of Minorities}

Art 27 of the ICCPR recognizes three types of minorities: ethnic, linguistic and religious minorities. ${ }^{13}$ A federal system is more suitable to accommodate such minorities and to ensure respect for identities. It should, however, be noted that protection of minorities is not only about equal political participation as will be elaborated later. It should also be noted that though we are preserving group identity, the rights of minorities are individual rights granted for those who belong to the minority group. ${ }^{14}$ Every person belonging to a minority group has, thus, the right, in community with others, "to enjoy culture, profess religion and use language." ${ }^{\prime 15}$ Although such rights are recognized as individual rights, a group of individuals belonging to the minority group or the minority group as a whole may be affected similarly and may bring action together through a representative. ${ }^{16}$ Protection of minority groups cannot be realized without providing such groups with participatory rights. Thus accommodation of such minority group through participatory rights (in addition to the granting of minority oriented rights) is an important aspect of protection of minorities. ${ }^{17}$

\subsection{Who are minorities?}

There is no a universally accepted definition of minorities in spite of many attempts by scholars. Although the protection of minorities was one of the

${ }^{11} \mathrm{http}: / / \mathrm{www}$. legalservicesindia.com/articles/c1onst.htm

${ }^{12}$ Art VI, clause 2 of US Constitution.

${ }^{13}$ Art 27 of the ICCPR. This provision provides that in countries where ethnic, linguistic and religious minorities exist, every one belonging to such minority group should not be deprived of his right together with the group to manifest and use their culture, religion and language.

${ }^{14}$ Human Rights Committee, General Comment 23, Art 27, 1994, U.N. HRI/GEN/1/Rev.1, pa. 3.1 p. 1.

${ }^{15}$ Id. pa, 1 p. 1.

${ }^{16}$ Lubicon Lake Band Vs Canada, Communication No. 167/1984, (March 1990), pa.32.1 p. 23.

17 Robert F. Williams, Josef Marko and Allan Tarr (2004), Federalism, sub national constitutions, and minority rights, Westport, CT, p. 42. 
agenda of the League of Nations, ${ }^{18}$ there was no attempt at that time to define the term 'minority'. The UN Charter does not make reference to minority rights or minorities. ${ }^{19}$ The UDHR too emphasizes on the general non-discrimination principle without giving special account for the rights of minorities.

The General Assembly took the view that it was "difficult to adopt a uniform solution" to this intricate problem as the question regarding minorities is different across countries. ${ }^{20}$ The International Covenant on Civil and Political Rights (ICCPR) provides protection for minorities without defining who minorities are. It states that "in those states in which ethnic, religious or linguistic minorities exist, persons belonging to such minorities shall not be denied the right, in community with the other members of the group, to enjoy their own culture, to profess and practice their own religion or to use their own language." ${ }^{\prime 21}$ This is the only provision about minority rights protection under the ICCPR which provides some factors that are helpful in determining minorities i.e. ethnicity, language, and religion. However, it fails to provide a definition and does not therefore, answer the question: which ethnic, linguistic, and religious groups within the states are minorities?

Even though the Human Rights Committee, in its General Comment 23 on Article 27 of the ICCPR, tried to make clarification on the rights of minorities, it does not attempt to approach the question directly. Its clarification was, however, helpful to understand the scope of the notion of minority. ${ }^{22}$ The General Comment makes it clear that the ICCPR does not only apply to national minorities but also covers migrant minorities as it does not make distinction between nationals and foreigners. ${ }^{23}$ However, the General Comment of the Human Rights Committee is not binding on the international community, and the Framework Convention of Europe employs the term "national minorities". ${ }^{24}$ This Framework Convention does not provide any definition regarding minorities. ${ }^{25}$

The definition given by Francesco Capotorti is widely used. This definition does not, however, answer all questions about minorities. His definition reads:

18 Steven Wheatley (2005), Democracy, minorities and international law, Cambridge University Press, p. 10.

${ }^{19}$ Ibid.

${ }^{20}$ Supra note 17.

${ }^{21}$ Art 27 of ICCPR.

${ }^{22}$ Human Rights Committee, General Comment 23, Art 27, 1994, U.N. HRI/GEN/1/Rev.1, pa 5.2 p 2 .

${ }^{23}$ Ibid.

24 The Framework Convention for the Protection of National Minorities, Strasbourg, 1.II.1995.

${ }^{25}$ Ibid. 
A group numerically smaller to the rest of the population of the state, in a non-dominant position, whose members -being nationals of the statepossess ethnic, religious or linguistic characteristics differing from those of the rest of the population and show, if only implicitly, a sense of solidarity, directed towards preserving their culture, tradition, religion or language. ${ }^{26}$

If there is one majority group over the rest of the population $(50 \%+1$ of the whole), then that group cannot be a minority. ${ }^{27}$ However, there may be a situation where there is no any ethnic, linguistic or religious group which is a majority out of the whole population. ${ }^{28}$ Even though the above definition is very important in determining minorities, it cannot be free from criticism. The definition is narrow in scope as it employs the phrase 'nationals of state'. ${ }^{29}$ International law has extended its scope to protect the rights of individuals irrespective of nationality. According to the above definition, it is difficult for migrants to claim linguistic, cultural and religious rights unless they get nationality. It is up to the states to grant nationality and thus migrants will be systematically left behind if we follow the above definition. ${ }^{30}$

Most federal systems have no clear rights of minorities regime under their constitutions. Under the US Constitution, there is no reference to minorities. There is a modicum of affirmative action (promoting disadvantaged groups) to bring real equality but not to preserve diverse identity. In India some religious groups are recognized as minorities. ${ }^{31}$ The case in Ethiopia is relatively complex. Even though Ethiopia has more than 80 ethnic groups, most of which are minorities, the Constitution does not directly address the issue of protection of minorities. It has also used the terminology 'minority nationalities and peoples' instead of 'minorities'.

According to the FDRE Constitution, only the "nations, nationalities and peoples"32 of Ethiopia may be determined as minorities. Such nations, nationalities and peoples of Ethiopia are those groups of people who satisfy two requirements under the Constitution; those having common culture, language or religion and constituting identifiable territory under Art. 39 of the FDRE

${ }^{26}$ Francesco Capotorti (1977), Study on the rights of persons belonging to the ethnic, linguistic and religious minorities, United Nations, para. 568.

27 Steven Wheatley (2005), Democracy, minorities and international law, Cambridge University Press, p. 19.

${ }^{28}$ Ibid.

${ }^{29}$ Supra note 26.

${ }^{30}$ Perry Keller (1998), "Re-thinking Ethnic and Cultural rights in Europe", Oxford Journal of Legal Studies, Vol. 18, 31-33.

${ }^{31} \mathrm{http}: / /$ www.countercurrents.org/commpuniyani101005.htm

${ }^{32}$ Art 39 (5) of the FDRE Constitution. 
Constitution. ${ }^{33}$ It means that those minorities who have no identifiable territory because they are dispersed over the country have not been envisaged as minorities under the Constitution.

Thus, there is the need for a legally binding definition to the term minority at domestic and international levels in order to prevent abuse from states against minorities. The difficulty then is the issue of diversity because it has distinct features in different countries. It was because of this problem that the ICCPR, while recognizing rights of minorities, failed to define who minorities are. Giving recognition for the rights of minorities under international human rights conventions or within federal constitutions without defining the term would undermine the rights of minorities as it would give states discretionary power in determining minorities and that may lead to systematic exclusion of minorities.

Some modification on the definition given by Francesco Capotorti ${ }^{34}$ could avoid the confusion over the subject. The basic problem with Francesco Capotorti's definition is that it fails to protect non- nationals as it employs the term 'nationals'. It means that by using the term 'persons' (like Art 27 of the ICCPR) instead of 'nationals', we can protect all individuals who belong to a minority group. Such modification is crucial, particularly, for migrant workers who could be denied citizenship systematically. Once we determine minority groups, then we can provide them with defined rights.

\subsection{Recognition of rights of minorities and participatory rights}

The general non-discrimination principle is a human rights notion which is applicable for all human beings irrespective of the fact that an individual belongs to a minority or majority group. ${ }^{35}$ Human rights are implemented based on the principle of equality and they uniformly apply to everyone. The protection of minorities is an additional mechanism for specific group of persons who are determined as ethnic, linguistic or religious minority. ${ }^{36}$ While non-discrimination principles in international and national legal documents are there to avoid discrimination, i.e. different treatment which is committed most of the time against minorities, the rights of minorities are introduced to preserve differences (identities) by providing special rights. ${ }^{37}$

Such treatment of the minorities should not be confused with positive discrimination/affirmative action which has the aim of achieving equality. Affirmative action is temporary, while the rights of minorities are permanent.

\footnotetext{
${ }^{33}$ Ibid.

${ }^{34}$ Supra note 26, para. 568.

${ }^{35}$ Supra note 22, para 1, p.1.

${ }^{36}$ Ibid.

${ }^{37} \mathrm{http}: / /$ www.ohchr.org/Documents/Publications/FactSheet18rev.1en.pdf
} 
Such rights should not also be taken as special benefits for a minority group. ${ }^{38}$ They are rather inherent in a minority group and are recognized to allow members of such group enjoy what their language, culture and religion offers. ${ }^{39}$ There is the need for such rights as long as we have ethnic, linguistic or religious minority even in settings where affirmative action is not necessary.

Recognition of the rights of minorities would also mean increasing the scope of social values. Such rights preserve ways of life including cultural, religious and linguistic values thereby increasing the opportunity to choose among the ways of life ${ }^{40}$ on our planet. Any one from the majority or minority group should have the freedom to choose the way of life which is most important to $\mathrm{him} / \mathrm{her}$. Indeed, recognition of and respect for the rights of minorities would advance equality although the basic rationale behind such rights is preservation of identity. ${ }^{41}$ Full realization of these rights is possible only through the accommodation of minority groups in a political process. The question of who shall be granted participatory rights in this regard is directly related to another important question as to why we need to grant such participatory rights for a group. $^{42}$

\subsection{Participatory rights that should be claimed by minorities}

As Williams and Marko noted, "participation rights should promote integration without ethnification of politics". ${ }^{43}$ The Ethiopian ethnic federal system does not seem be in conformity with this view. The organization of regional political entities in Ethiopia is based on ethnicity. Thus, mere citizenship does not enable citizens to actively participate in politics if they are not members of the ethnic group of a region even if they are living there for life. The secession clause in the Constitution adds fuel to the ethnically organized society. On the contrary, modern societies need integration and harmony in various pursuits.

In India, although there are some regions which are organized based on religion or ethnicity, the central government has strong constitutional powers to hold the units together. In the US too, the constitutionally proclaimed supremacy of federal laws and decisions over the laws of states is a reflection of supremacy of the federal government to the required degree. In Ethiopia, the federal government is influential because of the party system. If the dominant party system fails in the future, there is no guarantee to ensure unity unless some constitutional amendments are made.

\footnotetext{
${ }^{38}$ Supra note 22.

${ }^{39}$ Ibid.

${ }^{40}$ Supra note 30.

${ }^{41}$ Supra note 22.

42 Supra note 17.

${ }^{43}$ Supra note 17, p. 45.
} 
In any federal system where diversity exists, two basic interests must be balanced regarding participation rights, because neglecting these interests can lead to conflict and disintegration. On the one hand, the groups must "have an effective say" in the political process. ${ }^{44}$ On the other hand, the "influence given to the groups must not be so strong that they can completely paralyze the system". ${ }^{45}$ Williams and Marko made it clear that "participation rights ought not to lead to a situation in which political mobilization is based exclusively or primarily on ethnic arguments". ${ }^{46}$

\section{Representativeness of Shared Federal Institutions}

\subsection{The need for and representativeness of shared federal institutions}

Mere existence of principles of federalism on paper does not solve problems of plural societies. The practical accommodation of diversity is necessary to build lasting unity. Federalism is a means to reconcile clashing groups and thus political accommodation and mutual understanding among the diverse society is an essential element in every federation. ${ }^{47}$ As Watts clearly explains, every federal system has two basic purposes: namely ensuring self-rule through constitutional division of political power and (at the same time) achieving unity through shared federal institutions by working together on areas of conjoint interest. ${ }^{48}$ Here, legitimacy and efficiency of shared federal institutions are essential. Watts has made it clear that "representativeness within the institutions of the federal government of the internal diversity within the federation and effectiveness in the federal government decision making" are necessary if shared federal institutions are to be acceptable by citizens of constituent units. ${ }^{49}$

Representativeness of the federal legislature, executive and other federal institutions needs special consideration in this regard. While India and the US have bicameral federal legislatures, Ethiopia has a two-house parliament but a one-house (unicameral) legislature and this raises questions as to the legitimacy and representativeness of the federal legislature of Ethiopia. The head of government in the US is the president who is directly elected by the people. Ethiopia and India, on the other hand, have the prime minister as the head of government. Such differences in the arrangement of federal institutions have practical implications in the functioning of federations. For example, though the Ethiopian and Indian parliamentary form of government, with the prime

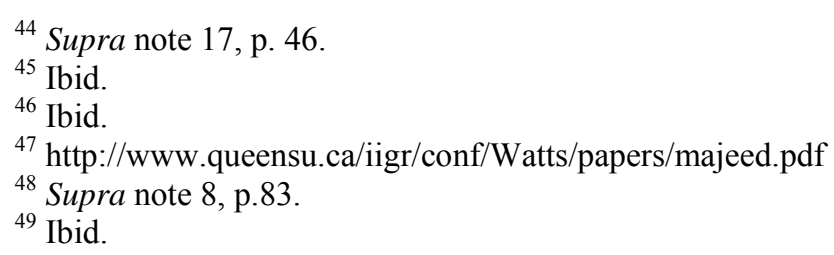


minister being the head of government, may be helpful to establish effective executive decision making, there is a problem of executive dominance through party discipline. In this case, the representativeness of the federal government will be questionable. On the other hand, even though there are good checks and balances in the US presidential form of government, there is a risk of standoff while making decisions especially when the president and the Congress are from different parties.

Whatever form of government a federation may have, there are shared federal institutions to hold the units together. Such institutions exercise power on areas of common interest like foreign affairs, defense and commerce. The role of shared federal institutions especially in India and Ethiopia where diversity is so enormous is very important to hold the units together as there is high potential for conflicts and disintegration. One way of accommodating regional interests in the federal shared institutions is through the upper house. While the US federal system provides two seats uniformly for each state, whether it is large or small, in the Senate ${ }^{50}$ the House of Federation ${ }^{51}$ in Ethiopia and the Indian Rajya $\mathrm{Sabha}^{52}$ do not follow such uniform seat allocation. Indeed, such uniform allocation does not work for the two federations as they are composed of societies with high diversity. An inequitable distribution of power among the ethnic and linguistic groups at the federal level is a prominent problem and source of conflicts in Ethiopia and India.

In Ethiopia, the question raised by nationalities to get an equitable share of power at the center is still left unsettled. Diverse groups strive to control power at the center which leads to continuous conflicts and instability. Thus, it is obvious that fairly distributed power among the nationalities is necessary if the tension among plural societies is to be addressed. Government systems in Ethiopia, including the present one, have failed to address the questions raised by nationalities and this is the reason for successive conflicts and removal of government systems by war. ${ }^{53}$

${ }^{50}$ Art I section 3 of US Constitution.

${ }^{51}$ Art 61 of the FDRE Constitution. The House of Federation in Ethiopia is the second chamber or the upper house, a federal shared institution, which is established to represent the interest of nations, nationalities and people as defined under Art 39 of the constitution.

52 Art 80 of the Constitution of India. Rajya Sabha is the upper house in India. It is composed of 250 members. Twelve of them are appointed by the president and they are experts in specific fields.

$53 \mathrm{http} / / / \mathrm{www}$.google.hu/search?q=www.oromopeoplescongress.org\%2Fdocs\%2FMereraOSA-paper. Merera Gudina, "The Ethiopian State and the Future of the Oromos: The Struggle for 'Self-Rule and Shared-Rule", paper presented in OSA Annual Conference, Minneapolis, USA, 2006, pp. 2-12. 
Power sharing that was promised in 1991 during the establishment of the transitional government is incorporated in the current Constitution. The Ethiopian government has also repeatedly claimed that it is progressively realizing what has been promised under the Constitution. However, de facto single party system has continued to be a serious challenge to the realization genuine federalism in Ethiopia. ${ }^{54}$ It was the failure to address the question of nationalities which resulted in the removal of the Derg regime. ${ }^{55}$ Yet, the current ruling party which came to power by war relies on its military power by setting aside the promises for equitable distribution of power at the federal level among nationalities and thus the tension among ethnic groups remains unsettled.

The popular discontent in 2016 has signaled some structural and operational problems with the Ethiopian ethnic federal system. The Constitution, for example, lacks clarity on intergovernmental relations within the federation in general and between the Oromia region and the capital, Addis Ababa, in particular. Such lack of clarity coupled with over 25 years of ethnification has resulted in popular discontent which forced the government to cancel the Addis Ababa and Oromia Special Zone Integrated Master Plan. ${ }^{56}$ The issue of Welkait, which has been initiated by the leaders of the community peacefully, did not also receive the government's willingness to handle it according to the constitutionally proclaimed procedures and this had fermented anti-government resentment in the Amhara region. ${ }^{57}$ This author does not suggest ethnic federalism. However, given the fact that the Constitution grants unconditional right to the nations, nationalities and peoples to decide their own fate (including secession) and because the government has stated this right as the pillar of the existing federal system, negating identity related issues would stand against the fundamental principles of the Ethiopian ethnic federal system. That in turn would erode trust on the government.

Needless to say, a federal system that merely gives territorial autonomy to a country's ethnic, linguistic or religious groups could not be sufficient, in multicultural federations like India and Ethiopia, to ensure respect for rights of minorities. In both countries, there are minority groups scattered over different areas, and, in effect, they do not occupy a defined territory. In Ethiopia, for example, there are about 80 ethnic groups, but only 9 states and two city administrations. This would mean that there are many ethnic groups (minorities in the various regional states) that could be excluded.

\footnotetext{
54 Ibid.

55 The socialist Dergue regime was removed after a bloody war caused by the then policy which suppressed opposition groups.

${ }^{56} \mathrm{http}$ ://addisstandard.com/why-resist-the-addis-abeba-master-plan-a-constitutional-legalexploration/

${ }^{57} \mathrm{http}: / /$ www.bbc.com/news/world-africa-36940906
} 
In a nutshell, unless the interests of ethnic, linguistic or religious groups are accommodated through federal shared institutions equitably, there will always be a high potential for conflicts. Mere enactment of laws that adhere to federal principles cannot create harmony and unity within diversity unless there is genuine share of political power which enables these groups to secure their interests under the federal setup. Failure to establish inclusive shared federal institutions thus poses a threat to a union in a federal system.

\subsection{Representativeness of the federal legislatures and minorities' protection}

It is through laws made by the federal legislature that a federal system achieves its goals regarding areas of common interest. As long as the federal legislature lacks legitimacy, or if it is not a genuine representative of different groups within a federation, the federal system cannot effectively function in a stable manner. For a federal legislature to be a legitimate representative, it has to satisfy two things. First, as federalism is about unity in diversity, the federal legislature has to constitute both elements of unity and diversity. It should thus include both the lower and upper houses. Second, chambers represent diverse interests and lower houses represent the interests of all citizens in the federation. If one house is excluded, it means that one element of federalism is missing.

The Ethiopian unicameral legislature fails to include one of these elements as the House of Federation (the upper house) does not participate in the lawmaking process. It is only the lower house (House of Peoples Representatives) which can make laws. ${ }^{58}$ This means that it fails to satisfy the yardstick for legitimacy of a federal legislature. Both the $\mathrm{US}^{59}$ and India ${ }^{60}$ have bicameral legislatures in which both the lower and upper houses participate in lawmaking. The second element for a federal legislature to be legitimate is that the upper house must genuinely represent diversity and the lower house must represent unity.

In the US, the upper house (the Senate) has two members from each state (Art I section 3) and its members are elected directly by the people (Amendment XVII). Thus, the US upper house represents both small and larger states equally and this can avoid domination of large and populous states over small ones. Yet, such a system can ensure equality only between states but not among diverse groups. Minority groups within a regional state could be dominated by the majority group in that state although the state is represented equally with other states at the federal level. The emphasis on the well-established egalitarian principles including individual liberalism, equality and non-discrimination in the

\footnotetext{
${ }^{58}$ Art 55(1) of the FDRE Constitution.

${ }^{59}$ Id., Art I section 1.

${ }^{60}$ Art 107 of the Constitution of India.
} 
US has made preservation of diversity and minorities' protection less important issues in the country.

The upper house in India (the Council of States or the House of Representatives of States, Art 80), like the US senate, represents states and not diversities per se. In addition to its failure to represent diversity, the Indian upper house can also be dominated by the largest states as the seats are allocated based on proportional representation principle (i.e. seats are allocated based on population size of constituent units).

The House of Federation (the upper house in Ethiopia) represents diversity although the allocation system enables the largest regional states to dominate smaller ones as each nationality, in addition to its one seat right, can have extra seats for each one million population. ${ }^{61}$ The House of Federation represents diversity as members are representatives of nations, nationalities and peoples of Ethiopia. But the House of Federation has no lawmaking role. There are two prominent problems with the Ethiopian upper house. First, it is dominated by few larger nationalities as they can have more seats for every one million extra population in addition to their rights for one seat. Secondly, it has no power to vote on laws. The basic reason behind the past conflicts and removal of government systems by war was the absence of a genuine share of power at the center. This has continued because, as Shola Omotola states, "real power is exercised in centralized fashion" by the ruling party and its ethno-national satellites under ... tight control ...". 62

The Constitution recognizes equality among the nationalities and their right to self-determination up to secession. The right to secessions is not incorporated in other modern federations. Thus, if one takes a look at the Constitution without considering what the reality on the ground is, he/she may say that the nationalities (which are ethnic groups in Ethiopia) are given unlimited rights and are more autonomous than other nationalities anywhere in the world. But the way the federation operates is far from what the Constitution has declared. As Merera, an opposition party leader, stated in his speech on a political debate, there is no genuine sharing of power and democracy in Ethiopia. ${ }^{63} \mathrm{He}$ has mentioned and underlined this again during the 2015 Ethiopian general election debate aired by the Ethiopian Broadcasting Corporation (EBC) ${ }^{64}$ Merera, in his

${ }^{61}$ Art 61 sub article 2 of the FDRE Constitution.

62 J. Shola Omotola (2006), Review of Ethnic Federalism: The Ethiopian experience in comparative perspective, edited by David Turton, Oxford: James Currey, p.305.

${ }^{63}$ Ethiopian Television, Feb, 12, 2010, speech by, Dr Merera on the first-round debate ahead of the May 2010 election.

${ }^{64}$ Ethiopian Broadcasting Corporation (EBC), March 13, 2015. 
speech, stated that "the EPRDF/ruling party governance system in Ethiopia falls under the category of pseudo democracy."65

The legitimacy deficit in the federal legislature, single party dominance and party discipline have resulted in a centralized political system while the Constitution has established a federal system. As I have explained before, the federal legislature of Ethiopia does not reflect diversity as the upper house which represents nations, nationalities and peoples of Ethiopia has no power to vote on laws. This means that the system cannot adequately resolve the problem of diversity unless a bicameral legislature is established. The Ethiopian federal system should thus draw lessons from the US, India and other federal systems to set a legitimate legislature suitable to address problems in a federal system. When we see the role played by second chambers, in almost all federations except a few like Ethiopia, they have significant say in law making process.

\subsection{Electoral systems and their impact on minorities' protection}

The type of electoral system followed by federal countries has an impact on representation of diverse interests. ${ }^{66}$ Members of the lower house in Ethiopia, ${ }^{67}$ India ${ }^{68}$ and the US are elected based on a "single member constituency plurality electoral system." ${ }^{\prime 9}$ Other federal systems including Switzerland employ proportional representation with a view to accommodate minority political parties to represent the interests of minority groups. ${ }^{70}$

There are problems with both types of electoral systems. While the electoral system adopted in the US, India and Ethiopia may enable these federations to establish effective and stable legislative bodies, this happens at the expense of underrepresentation of minority parties ${ }^{71}$ and ultimately this has adverse impact on the representation of diversity within these federal systems. To avoid problems of underrepresentation produced by "plurality-majority voting systems", the proportional representation system is introduced in most (21 out of 28) of the countries in Western Europe. ${ }^{72}$ But, it is difficult to establish a stable legislature and, most of the time, there will be coalitions of political parties to form the executive as there is a low chance for one party to form a

\footnotetext{
${ }^{65}$ Ibid.

${ }^{66}$ Supra note 8 , p. 90.

${ }^{67} \mathrm{http}: / /$ www.electionsethiopia.org/Electoral\%20System\%20print.html

${ }^{68} \mathrm{http}: / /$ www.cfr.org/publication/19105/indias_electoral_politics.html

${ }^{69}$ Supra note 8.

${ }^{70}$ Ibid.

${ }^{71}$ Ibid.

${ }^{72} \mathrm{http} / / /$ www.mtholyoke.edu/acad/polit/damy/BeginnningReading/PRsystems.htm
} 
majority. That in turn leads to frequent disagreements on how to govern a country. $^{73}$

It is obvious that the proportional electoral system is fair and more inclusive than the single member plurality electoral system. Especially, in federations like Ethiopia where the second house which represents diversity has no lawmaking power, it is necessary to introduce a more accommodative electoral system to enable different groups to have a say in the lower house. As explained in the previous sections, the upper houses of the US, India and Ethiopia lack one or more elements to be genuine representatives of diverse interests. The Ethiopian and Indian upper houses are more problematic because they fail to avoid control of the upper house by larger states.

Election of members of the second chamber of India and Ethiopia is by the legislatures of regional states. This creates an additional problem in the functioning of the federal system as there will be an opportunity for a ruling party to control this house through a party discipline system. In such a case, members cannot serve as real representatives of either the interests of regional states or diverse groups of people in a region. To ensure that those neglected groups in the past are well represented in the federal lower house, the Constitution of India has obliged states to reserve seats for scheduled Tribes and Castes. This is a relevant step to represent a particular group in the lower house as candidates belonging to that particular Caste or Tribe are elected only to represent that group. But, the total number of reserved seats is lower than half of the number of members of the lower house and it is difficult to influence the majority in this house unless such scheme is supported by wisely designed upper house. Proportional electoral system or reservation of a significant number of seats for marginalized groups and a representative upper house with a lawmaking role are necessary for a federal system in general and particularly where it is multicultural.

\section{Potential Threats to Unity in a Federal System}

In every federation, there are potential factors which lead to conflict and, in serious cases, total collapse of a federation. A federation needs formal institutions and principles of intergovernmental relationship (IGR) to handle such problems amicably. The Ethiopian IGR system is mainly informal dominated by the ruling party. ${ }^{74}$ As Burgess explains, "the coexistence of self-

${ }^{73}$ Pippa Norris (1997), “Choosing Electoral Systems: Proportional, Majoritarian and Mixed Systems”, International Political Science Review, Vol. 18, No.3, 297-312.

74 The Ethiopian House of Federation (2015), The concept of Intergovernmental Relations, countries' experience and the context in Ethiopia, a report presented on Intergovernmental Relations Conference, March 2015, Addis Ababa, Ethiopia. 
rule and shared rule means that conflict, competition and cooperation are institutionalized in a peculiar way that perpetuates problems of great complexity" ${ }^{75}$ There will be more dangers to unity in a federal system if constitutional and political mechanisms are not employed to handle potential sources of conflict.

As the units of a federal system form a federation to maintain a balance between unity and diversity, strengthening unity or diversity alone may result in the collapse of the federation. Too much emphasis on unity may gradually take away the powers of constituent units. That may force member states to leave the federation. Excessive emphasis on diversity is also equally dangerous to a union in a federation. It, in the long run, may make states stronger than the federal government and that may enable them to ignore the federal government and secede from the federation unilaterally.

Most of the time, excessive asymmetry of power, absence of supremacy clause to settle conflicts between federal and state jurisdictions, arranging boundaries of a federation based on ethnicity (ethnic federalism), constitutional secession clause and failure to represent diversity in federal institutions are among the potential sources of conflict which endanger union in a federation. This section will focus on these potential dangers to unity in a federal system.

\subsection{Excessive asymmetry of power}

As explained in the previous section, there is asymmetry of power in every federation. Political asymmetry, in particular, is unavoidable as it is caused by differences in terms of population size, skilled manpower, resources and other factors. There is also constitutional asymmetry in some federations. Asymmetry of power becomes a source of conflict and instability when it is undesired or excessive. As Govinda Rao and Nirvikar Singh stated:

Asymmetry in administrative, political and economic spheres in federal systems is unavoidable and in fact, may be necessary not only to 'come together' but also to 'hold together'. However, while transparent asymmetric arrangements that can be justified on grounds of overall gains to the federation contribute to nation building, the discriminatory policies followed purely on short term political gains can be inimical to the long term interests and stability of federalism. ${ }^{76}$

Asymmetry of power will be excessive in more centralized federations and the worst scenario will be in case there is/are state/s which is/are stronger than the centralized federal government. ${ }^{77}$ In a centralized federation, the central

\footnotetext{
${ }^{75} \mathrm{httpwww}$.queensu.caiigrconfWattspapersBurgess.pdf

${ }^{76}$ M.Govinda Rao and Nirvikar Singh, "Asymmetric Federalism in India: Unequal arrangements”, p. 31. httpwww.nipfp.org.inworking_paperwp04_nipfp_006.pdf

${ }^{77}$ Ibid.
} 
government has more discretionary power than a non-centralized one and that may lead to asymmetrical treatment of constituent units. If such centralized federal system is controlled by only a few states or where there is/are state/s which is/are stronger than the central government, there will be much more room for discrimination against the remaining states and that worsens the asymmetry of power as the stronger states will tend to stand for their own interest. Based on the Indian scenario regarding this problem, Govinda Rao and Nirvikar observed that "the states ruled by regional parties with significant strength in the parliament (federal parliament) have become pivotal and have been able to secure substantially higher resources relative to other states. ${ }^{, 78}$ That would result in excessive or undesired asymmetry of power.

In India, there is a growing trend of asymmetry of power. While some constitutional and political asymmetries that have developed in India are appropriate for the smooth functioning of the federation, there is excessive asymmetry of power which is caused by "changing configuration of political power structure, vagaries of coalition and regional party politics" $" 79$ and that could be a danger to the union in the long run. ${ }^{80}$

As explained earlier, political asymmetry of power is unavoidable. It can only be minimized by using constitutional asymmetry which may be helpful to address challenges from influential constituent units. But, in the long run it may have a divisive impact. As the experience in India indicates, granting special rights for one or more states in a federation can induce others to claim similar special rights, and such competition may lead to conflicts.

Both the US and Ethiopian federations are constitutionally symmetric. The states in these federations have equal rights and powers. But, there is political asymmetry in both federations like all other federations. In the US, there are also non-state units which are treated asymmetrically. Such asymmetric treatment of non-state units is meant to address substantial differences. As G. Alan Tarr clarifies, "geographical position mattered in the case of island territories; differences in style of life and traditional forms of governance influenced the treatment of Indian tribes; and differences in ethnicity affected the status of Puerto Rico and other islands." ${ }^{\prime 1}$ What has to be noted here is that, unlike in India and Canada ${ }^{82}$, asymmetrical treatments in the US are not designed for component units (states). Rather, they apply to non-state units including non-state islands, the District of Colombia (where the nation's capital exists) and Indian tribes. Alan Tarr has explained this point:

\footnotetext{
${ }^{78}$ Id., p. 30.

${ }^{79}$ Id., p. 32.

${ }^{80}$ Ibid.

${ }^{81}$ Ibid.

${ }^{82}$ Supra note 8, p.66.
} 
Typically - particularly in multi-ethnic federations- it is the component units that seek distinctive (asymmetrical) arrangements as a means of recognizing and accommodating diversities. In the United States, in contrast, the asymmetrical arrangements were devised by and imposed by the federal government, and these steps were taken to serve national objectives, not the distinctive needs of the component units. ${ }^{83}$

Alan Tarr added that such arrangements in the US helped to avoid control of the nation's capital by a state ${ }^{84}$ and it provides "an orderly procedure whereby sparsely inhabited territories could be governed until population growth qualified them for statehood" ${ }^{85}$ Therefore, asymmetric treatment of non-state units in US is for the healthy functioning of the federation and it does not lead to conflict between states.

Even though there is constitutional symmetry of power in Ethiopia like in the US, the political party structure has resulted in undesired asymmetry of power. In reality, the ruling party controls the military and executive apparatus in Ethiopia. In this regard Lovise Aalen stated that "The TPLF was the creator of the coalition (EPRDF) and the architect of the ethnic federal model" and he further noted that "The TPLF, through the EPRDF coalition, has not been able to demonstrate a genuine will to share power with other political forces in a democratic manner". 86

\subsection{Constitutionally proclaimed right to secede}

While the US and Indian federations have indestructible union, ${ }^{87}$ the FDRE Constitution has established a destructible union. The US federation is "indestructible union of indestructible states" 88 and the Indian federation is "indestructible union of destructible states." the states are destructible, i.e. in principle, nations, nationalities and peoples of Ethiopia can secede from the federation or form their own state, zone or district within the federation. ${ }^{90}$

Article 39(1) of the Constitution of Ethiopia proclaims that "every Nation, Nationality and People in Ethiopia has an unconditional right to self-

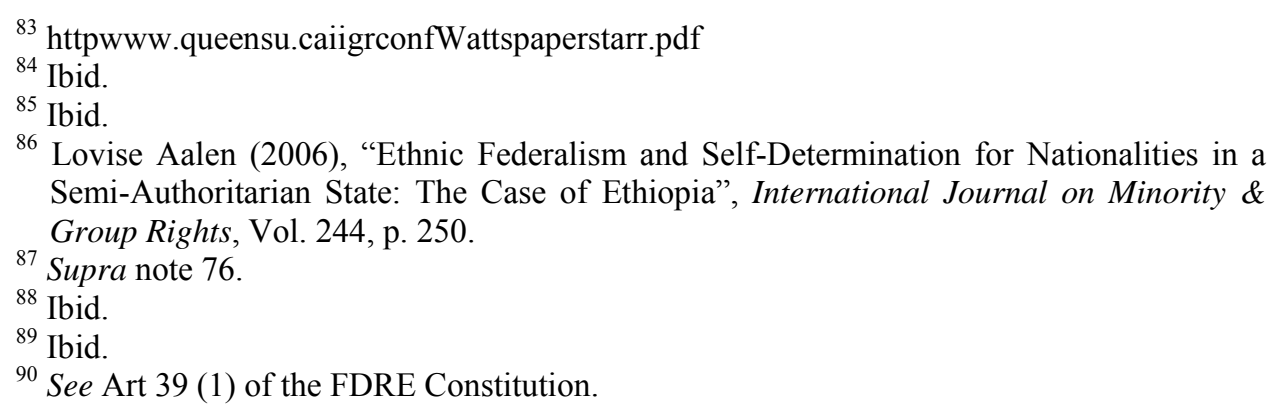


determination, including the right to secession". 91 "Right to self-determination short of secession" 92 is recognized in every federation to give autonomy to regional units or to protect rights of minorities. ${ }^{93}$ But, what is unique in Ethiopia is that there is a constitutional right to self-determination including secession.

International law is unclear as to whether right to self-determination includes the right to secede. The widely accepted approach is that the right to external self-determination (secession) is an exclusive right of nations "under colonial rule" 94 and its application beyond this is only in case of failure to include a nation in a democratic political process or when massive human rights violations occur. ${ }^{95}$ As Abate Nikodimos states, "if a government is democratic and inclusive, then the right has less international legitimacy." 96 While the FDRE Constriction is inclusive, the government has undermined the constitutional principles and there is no genuine share of power as I explained elsewhere. Failure to ensure equitable share of power on one hand and the constitutionally proclaimed unconditional and unilateral right to secede on the other have inspired some opposition groups to form military fronts to fight the present government to effect secession.

The secession clause under the FDRE Constitution, assuming that there is democratic environment to exercise it, is a time bomb for the union. Firstly, its incorporation under the Constitution may create a sense of leaving the federation and that may lead to bloody conflicts. Abate Nikodimos underlines that the "inclusion of the secession clause itself might encourage groups to try the option, and this might consequently create distrust and destabilizes the unity of the country". ${ }^{97}$ Nor can we be optimistic about post-session scenarios. One can recall the bloody war between Eritrea and Ethiopia just some years after the secession of Eritrea.

Secondly, when we see the right under the Constitution, it is unconditional and unilateral which would mean that, assuming that there is a democratic government, it is so easy for any nation, nationality or people to secede as long as the majority of the people concerned opt for it. The federal government or other states within the federation have no say at all regarding the secession

${ }^{91}$ Ibid.

92 Allen Buchanan (1995), "Federalism, Secession and the Morality of inclusion", Arizona Law review, Vol. 53, 53-63.

${ }^{93}$ Ibid.

94 Abate Nikodimos (2004), "Ethnic Federalism in Ethiopia: Challenges and Opportunities", Lund University (Student Paper), p. 57.

${ }^{95}$ Ibid.

${ }^{96}$ Id., p. 58.

${ }^{97}$ Id., p. 62. 
process and the nation which requests for secession does not have to provide the reason why it wants to secede.

As clearly stated under Art 39(1) of the Constitution, the right of nations, nationalities and people to secede is unconditional. ${ }^{98}$ The federal government is obliged by the Constitution to provide referendum for secession within three years after it received the request for secession which is approved by the "Legislative Council of the Nation, Nationality or People concerned." 99 Then, it is up to the people of such Nation, Nationality or People concerned to decide on whether to secede or not through the referendum. Therefore, secession under the FDRE Constitution is both unconditional and unilateral. Nor can state of emergency be decreed to 'suspend or limit' the right to secession because this becomes unconstitutional under Article 93(4)(c) of the FDRE Constitution.

No other federation in the world has a secession clause. This is because it can lead to unlimited fragmentation which goes against international law and global order. Unity, common defense, greater market and economic development and social cooperation are given emphasis in every federation. Thus, the secession clause under the FDRE constitution is among the unique features of the Ethiopian federation.

Of course, there are instances of secession questions even although other federations have no secession clause in their constitutions. The question of secession raised by Quebec can be cited as an example. But, what is constitutionally incorporated in Ethiopia and what is decided by the Supreme Court of Canada regarding secession are substantially different. While the Ethiopia's Constitution grants unconditional and unilateral right to secede, the Supreme Court of Canada rejected such unilateral and unconditional right to secede. It stated that, "while unilateral secession would be unconstitutional, a clear expression by the people of Quebec of their will to secede from Canada would impose a reciprocal obligation on all parties to Confederation to negotiate constitutional changes to respond to that desire". ${ }^{100}$ At this juncture, it should be noted that "self-determination short of secession"101, if implemented in a democratic way, can bring the desired autonomy.

\subsection{Arranging federal boundaries primarily based on ethnicity (Ethnic federalism)}

A federation may adopt a form of distributive or ethnic federalism in organizing its constituent units. While the purpose of distributive federalism is to divide power between the federal and regional states to ensure liberty and democracy

\footnotetext{
98 Art. 39 (1) of the FDRE Constitution.

${ }^{99}$ Id., Art. 39(4).

${ }^{100}$ Reference, Secession of Quebec, 1998, 2S.C.R.217, para.53.

${ }^{101}$ Supra note 92, p. 54.
} 
and thus is organized based on administrative convenience, ethnic federalism is moulded based on identity and its aim is to give power (autonomy) for each ethnic group. India has reorganized the states along ethnic and religious lines in 1966. ${ }^{102}$ Given the constitutional powers of the union in India, the federal arrangement which is organized based on linguistic and religious identities is not a threat to the union though the tension it creates between ethnic groups may lead to continuous conflicts among the tribes, castes, provinces or territories. The union has the right to reorganize the states, it can merge two or more states into one, it can establish new states from one or more existing states and it can direct states to execute the laws in a manner it deems necessary.

What is more, the centralized court system, the federal legislature's power to enact laws in the national interest on any area which belongs to states and the union's power to change the federation into a unitary form of government in case of emergency are all meant to maintain unity.

In view of historical experiences of disruptive and disintegrative sectarian forces and the political context of partition prevailing at the time of independence, the founding fathers of the Indian Constitution wanted to strengthen the Union against possible disintegrative pressures. ${ }^{103}$

Ambedkar, one of the drafters of the Indian Constitution, had stated during the discussion on the draft constitution:

Though India was to be a federation, the federation was not the result of an agreement by the states to join in a federation. Not being a result of an agreement, no state has the right to secede from it. Though the country and the people may be divided into different states for convenience of administration, the country is one integral whole, its people a single people living under a single imperium derived from a single source. ... The Drafting Committee thought it was better to make [this] clear at the outset rather than leave it to speculation... ${ }^{104}$

The form of ethnic federalism introduced in Ethiopia is different from what is adopted in India. As Minasse explains, "although the Indian Constitution of 1950 has been thought to have served as a model emulated by the drafters of the Ethiopian Constitution, the similarity between the two constitutions is superficial". ${ }^{105}$ According to Minasse, there are conditions in India which can ensure the integrity of the federation and those conditions are lacking in

\footnotetext{
$102 \mathrm{https} / /$ www.stratfor.com/analysis/telangana-decision-microcosm-indias-geopoliticalchallenge

${ }^{103} \mathrm{http} / / / \mathrm{www} . u n u . e d u /$ unupress/unupbooks/uu12ee/uu12ee0j.htm

${ }^{104}$ Ibid.

${ }^{105}$ Minasse Haile, "The new Ethiopian constitution and its impact up on unity, human rights and development", Suffolk Transnational L. Rev. Vol. 1, 1996-1997, p. 17.
} 
Ethiopia. ${ }^{106}$ The FDRE Constitution has used language and ethnicity in organizing the states and every group which is identified as a "nation, nationality or people" ${ }^{" 107}$ has the right to self-determination including secession. Though the undemocratic nature of the ruling government has left the constitutional provisions untested, full implementation of the ethnic arrangement introduced in the Constitution will be so hazardous for stability of the federation.

According to Minasse, the ethnic federal arrangement established by the Constitution has introduced perplexing and damaging structures which inspire tribal groups to fight each other and that may lead to disintegration. ${ }^{108} \mathrm{He}$ further noted:

"the dangerous nature of the Ethiopian federation is found mainly in the near total transfer of sovereignty from the center to tribal regions, in the disproportionate powers allocated to the tribal sub-units collectively and individually and in the creation of a government of unlimited powers." 109

Careful reading of Arts 8 and 39(5) of the FDRE Constitution reveals that there is no sovereignty vested in the people of Ethiopia as a whole. Art 8 declares that sovereignty is vested in the "nations, nationalities and people of Ethiopia". 110 And when we see the definition of "nations, nationalities and people of Ethiopia" under Art 39(1), it does not refer to the people of Ethiopia as a whole; rather it refers to ethnic groups. ${ }^{111}$

Those individuals who have mixed identity or are advocates of Ethiopianism have to ascribe themselves to one of the ethnic groups in Ethiopia. They can be participants in the political process only if they attribute themselves to one of the ethnic groups. This has eroded the common destiny Ethiopians have for "millennia". ${ }^{112}$ It undermines the common historical, religious and social ties of all nationalities in Ethiopia including the victory of all nations, nationalities and people against foreign invasions at Adwa and other battlefields. The Northward movement and political domination of the Oromo over areas including Wello and Gondar in the 16 century and the Southward movement of the Amhara in

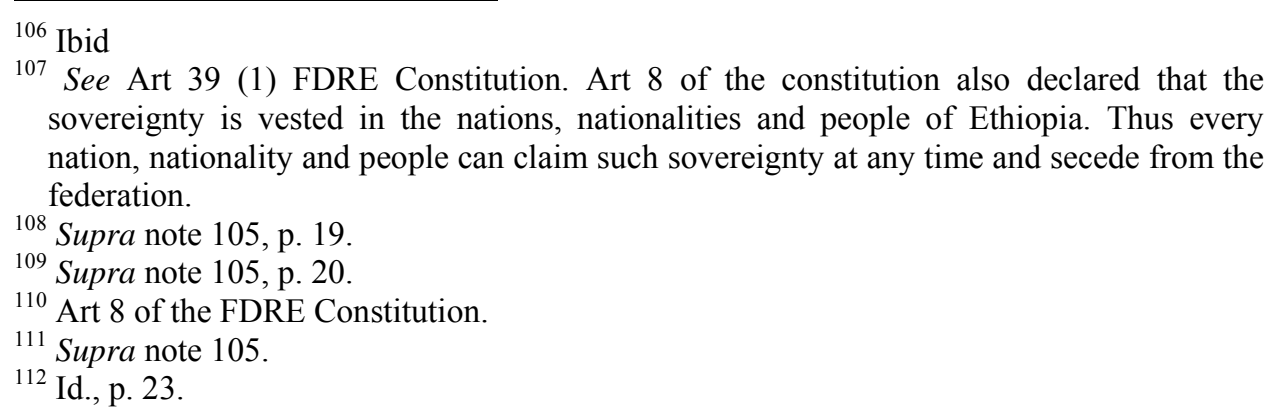


the 19 century ${ }^{113}$ are also among the significant historical events which link the Ethiopian people by blood and culture. It is to be noted that Imam Ibrahim (usually referred to as Ahmed Gragn) who had expanded his control to most parts of Ethiopia in the $16^{\text {th }}$ Century had established his capital in Dembia and not Harar. Thus, Ethiopian people have shared memories, assimilation, various moves of expansion, and blended values contrary to the misperceptions that are in the course of being nurtured as a result of the present ethnic federal system which is steadily eroding the elements of Ethiopianess in the identity of citizens and, in effect, creating the climate of fear, suspicion and hostility among ethnic groups.

Economically, it will be impossible to establish states for all ethnic groups. ${ }^{114}$ Thus, some groups cannot be influential enough to exercise their right to selfdetermination. Therefore, the ethnic federal arrangement may benefit only dominant ethnic groups. Even people who belong to such groups may be minorities in other regions and thus may not have the same autonomy their ethnic group enjoys on the territory it dominates.

As many opposition politicians argue, federalism is indispensable for Ethiopia but not ethnic federalism. ${ }^{115}$ The International Crisis Group has also warned against the danger the Ethiopian ethnic federal system. Its 2009 report states:

While the concept has failed to accommodate grievances, it has powerfully promoted ethnic self-awareness among all groups. The international community has ignored or downplayed all these problems. Some donors appear to consider food security more important than democracy in Ethiopia, but they neglect the increased ethnic awareness and tensions created by the regionalization policy and their potentially explosive consequences. ${ }^{116}$

Hence, the ethnic federal system in Ethiopia is a threat to integrity and nation building. Ethiopia's pre-1991 provinces were not organized based on language. The provinces facilitated interactions between Ethiopian people from different ethnic groups. Thus, solely using language as a means of political organization ignores other important factors. As Assefa Fiseha states, "restoration of Ethiopia's historic provinces and organizing them on a federal basis" ${ }^{117}$ can

\footnotetext{
113 Supra note 53, p.3.

114 Lovise Aalen, (2002), "Ethnic Federalism in a Dominant Party State: The Ethiopian Experience 1991-2000", Report R. 2002: 2, Chr. Michelsen Institute Development Studies and Human Rights, p. 44.

${ }^{115}$ Ibid.

${ }^{116}$ International Crisis Group report on Ethiopia: "Ethnic federalism and its discontents", Africa Report N ${ }^{\circ} 153$ - 4 September 2009, p. ii.

${ }^{117}$ Assefa Fiseha (2007), Federalism and the Accommodation of Diversity in Ethiopia: A Comparative Study, revised edition, Artistic Printing Enterprise, p.248.
} 
bring administrative convenience and it will be more accommodative as "provincialism is one element of diversity that defines Ethiopian society." 118 This can also minimize the asymmetry of power and tension among the ethnic groups.

\subsection{Lack of genuine representation of diversity}

As explained earlier, accommodation of diversity is one of the purposes of federalism in multicultural federal systems like India and Ethiopia. Accommodation or representation of diversity does not, however, necessarily need ethnic federalism. Accommodation of diversity and the establishment of a democratic environment that enhances the participation of diverse groups are crucial to avoid marginalization of some groups within a multi-cultural federation. If these conditions are lacking in practice, those groups left behind or groups which do not get appropriate share of power will opt to leave a union. Thus, failure to equitably represent diversity through shared federal institutions will create real threats to the integrity of a federation.

The core principle in the US federal system is 'liberal democracy.,"119 'Individual liberty' ${ }^{120}$ is thus the bedrock of the federation. Ethnic identity is not used as a basis in determining boundaries of the states and in sharing powers within the federation. This would mean that there will not be a question by a particular ethnic group to share power as one identified group within the federation. The fact that US federalism is based on liberal democracy does not, however, mean that diverse groups have no rights at all. Because of the wide exclusions of and discriminations against the minorities by the majorities in different states, the states have developed their own minority rights protection systems. As Alan Tarr explains, "state courts have responded with rulings granting protections for rights beyond those afforded by the federal constitution". ${ }^{121} \mathrm{He}$ states that, the state courts and constitutions play important roles in protecting minority rights. ${ }^{122}$

Unlike the US, the Ethiopian and Indian federal constitutions are committed to accommodation of diverse groups. The problem in both federations (Ethiopia and India) relates to the absence of accommodation in practice. The various issues discussed above including poor democratic culture in Ethiopia and disproportionate power given for the union of India are among the factors that have caused gaps in the accommodative environment. This has resulted in many

\footnotetext{
118 Ibid.

119 http://www.wisegeek.com/what-is-a-liberal-democracy.htm

${ }^{120}$ Ibid.

121 Supra note 17 , p. 90.

${ }^{122}$ Id., pp. 89-99.
} 
communal conflicts in India ${ }^{123}$ and has created ethnic tensions in Ethiopia including ethnic based military groups that are fighting against the Ethiopian government.

\section{Constitutional Review, Unity and Minorities' Protection}

Federal or quasi federal forms of government are more complex than unitary forms of government. The competition for power and resources among the constitutional actors within federations exposes them to disputes. This would mean that federal governments need to have strong and well organized constitutional umpire to handle horizontal and vertical disputes among constitutional actors. As federal constitutions divide power between the two levels of government and because such division of power has to be guaranteed for a system to remain federal, neither level of government should have unilateral power to interpret a constitution.

\subsection{Constitutional review: Who can request for it?}

While most countries have a system of constitutional review to evaluate the laws and decisions made by a legislative or executive body for their constitutionality, there is divergence in terms of the type of adjudicating body they adopt, the type of claim which can be made before this body, the sort of organizations or persons who can bring constitutional complaints and the composition of the adjudicating body. ${ }^{124}$ Such differences have an impact on the protection of minorities and maintenance of a union in a federal system. This would mean that federal systems need to have umpiring institutions which can keep the spirit of federalism in addition to the protection of individual rights and supervision of horizontal separation of powers which are also essential in the constitutional review schemes of unitary governments.

The issue as to who can request for constitutional review depends on the particular spirit or purpose that is pursued in a federal system. For example, as the US federal system is based on the principle of liberal democracy, the vertical and horizontal divisions of power are meant to achieve individual liberty and democracy. ${ }^{125}$ Group identity is not relevant under the US Constitution. This means, a group of people or a person belonging to this group has no standing to request for constitutional review before the US Supreme Court or other federal courts in order to claim a special right based on identity. As indicated earlier,

\footnotetext{
${ }^{123}$ Id. pp. 203-211.

${ }^{124}$ Tom Ginsburg (2008), Comparative Constitutional Review, University of Chicago, July 30, 2008, p. 1.

${ }^{125}$ See New York Vs United States, 505 U.S. 144, 112 S.Ct. 2408, 120. L.Ed.2d. 120, 1992, para. 16.
} 
there are state constitutions and courts which have developed minorities' protection systems and thus there may be such claims in these states.

In India and Ethiopia, ethnic, religious and linguistic groups are the central elements in the respective federations. Hence, an ethnic, linguistic or religious group or an individual belonging to this group may request for constitutional review to secure a right based on such identity. Thus the issue who has standing in a given federation depends on the particular purpose that federation wishes to achieve. These days, there is an increasing trend of allowing individual complaints for constitutional review with a view to protecting fundamental individual rights. ${ }^{126}$

A federation which can be an example for providing wider access for constitutional review is Germany. "State bodies of all levels, ordinary courts, the Lander, constitutional courts of the Lander and any individual (alleging violation of his/her fundamental rights) can bring constitutional complaint before the Constitutional Court and the Constitutional Court has the power of both abstract and concrete review. ${ }^{127}$ In the US, though there is no abstract review, anyone who satisfies general 'standing' requirements for litigation can raise a constitutional issue in court.

In India, Articles 12-31 in Part III of the Constitution provide fundamental individual rights and minority rights. ${ }^{128}$ Art 32 provides that the Supreme Court has the power of constitutional review to enforce these rights. ${ }^{129}$ Therefore, individuals, minority groups or an individual belonging to a minority group may bring constitutional compliant to the Supreme Court of India. But, the Supreme Court itself has very limited power of constitutional review. For example, the Supreme Court's decision on constitutionality can be reversed by the parliament through constitutional amendment in case the parliament is not satisfied with the Court's decision. ${ }^{130}$ In 1967, the Supreme Court confronted the influence exerted by the parliament by passing a landmark decision in the Golaknath case stating that fundamental rights cannot be amended. In Ethiopia, any interested party has the right to institute a constitutional complaint by virtue of Article 37 of the Constitution. ${ }^{131}$

\footnotetext{
${ }^{126} \mathrm{http}: / / w w w . c o n c o u r t s . n e t / l e c t u r e / l e c t u r e 4 . h t m l$

${ }^{127}$ Ibid.

${ }^{128}$ See Part III of the Constitution of India.

${ }^{129}$ See Art 32 of the Constitution of India.

${ }_{130} \mathrm{http} / / /$ nos.org/317courseE/L-15\%20judicial\%20review\%20and\%20protection.pdf

131 The House of Federation has also entertained a case submitted by Ethiopian Women Lawyers Association on behalf of Kedija Beshir and this shows that an individual, organization or association which is an interested party can institute a constitutional complaint to the Council of Constitutional inquiry. The final decision is passed by the
} 


\subsection{The adjudicating body that best serves protection of minorities and unity}

Historical, political, cultural and social differences among federations have led to the establishment of different institutions entrusted with the power of constitutional review. Supreme courts in federal systems including the US, Canada, Australia and India have the final say on constitutional matters. ${ }^{132} \mathrm{We}$ also find specialized courts that can exercise this power such as the German Constitutional Court. This is currently pursued in many federal and unitary states including Belgium, Comoros, Spain, Bosnia and Herzegovina, South Africa and Hungary. ${ }^{133}$ Ethiopia has followed a unique model. The power of constitutional review in Ethiopia is vested in a non-judicial political organization, the House of Federation. ${ }^{134}$

Four major arguments are forwarded in support of the House of Federation's power to adjudicate constitutional disputes. The first argument is that sovereignty under the Ethiopian constitution is vested in the nations, nationalities and peoples under Art 8 and as the Constitution, and since, the House of Federation represents these groups it is the proper organ to interpret the Constitution. But, this is not valid because it assumes that the federation is a coming together federation, i.e., one formed based on the free consent of nations, nationalities and peoples, which would mean that the nations, nationalities or peoples had had the capacity not to join the federation at the time. The constitution making process was under the control of the ruling party dominated by Tigray Peoples' Liberation Front (TPLF) and thus the Constitution cannot be seen as a genuine reflection of the will of nations, nationalities and peoples. To use the words of Lovise Aalen, "the process of drafting and ratifying the Constitution was totally dominated by the ruling party, and hence, the federal project lost legitimacy". ${ }^{135}$ One cannot, therefore, assume the Ethiopian federation as a coming together federation. Thus, the first reason which justifies constitutional review by the House of Federation is not tenable.

The second justification for vesting this power in the House of Federation is absence of confidence in ordinary courts because of the history of the Ethiopian courts. This argument is also weak as reform can make courts much better and impartial than a single party dominated political institution.

House of Federation as the Council of Constitutional Inquiry can only send an advisory opinion of the HoF.

${ }^{132}$ Supra note 8, p. 100. See also http://www.concourts.net/lecture/lecture4.html

133 Ibid.

${ }^{134}$ See Article 62 of the FDRE Constitution.

${ }^{135}$ Supra note 114. 
The third argument is that vesting this power in the judiciary is inappropriate as judges will give priority to legal values and disregard political elements in constitutional disputes. ${ }^{136}$ This argument may be persuasive but it does not lead to the inference that a political institution is the best alternative to adjudicate constitutional cases. Given the diversity in Ethiopia, ordinary courts may not be the right institutions to adjudicate all types of constitutional matters. Judges in the ordinary courts may give preference to mere literal readings of the law and fail to consider cultural, ethnic, religious, linguistic and other identities in exercising their power of constitutional review. But this does not justify the power of constitutional review by a non-judicial political institution (i.e. House of Federation) especially, when such political institution is controlled by a dominant party thereby lacking independence. It is indeed possible to establish a specialized court with specialized judges who can consider both legal and other legal factors. Thus, the German Constitutional Court can be adopted in Ethiopia with some modification.

It is, however, to be noted that a specialized court will be overburdened with cases and can be ineffective if all cases, including the ones that involve fundamental individual rights are directly brought to it. Ordinary courts can be proper judicial institutions to determine constitutional cases regarding such cases because they involve more legal than non-legal issues. Fundamental individual rights cases are frequent as they are everyday questions of citizens. Thus, ordinary courts need to have involvement in determining constitutional disputes concerning fundamental individual rights. But, there are other constitutional disputes which require the consideration of non-legal factors thereby necessitating specialized courts and judges to address such constitutional cases. Therefore, both ordinary courts and a specialized constitutional court need to have the power to determine constitutional disputes.

The fourth reason mentioned as a justification for constitutional review by the House of Federation is the argument that issues regarding horizontal separation of powers often involve both legal and political elements and thus courts may lack competence to adjudicate such cases. ${ }^{137}$ The US judiciary is mentioned as one example facing a problem in adjudicating such cases. ${ }^{138}$ It should, however, be noted that although the US Supreme Court had refused to

\footnotetext{
${ }^{136}$ Assefa Fiseha (2007), "Constitutional Adjudication in Ethiopia: Exploring the Experience of the House of Federation (HoF)", Draft paper presented at African Network of Constitutional Law Conference on Fostering Constitutionalism in Africa, Nairobi, April 2007 p.9-11.

${ }^{137}$ Supra note 117 , pp. 416-418.

${ }^{138}$ Ibid.
} 
issue mandamus ${ }^{139}$ against the political departments in Marbury v. Madison indicating that the case involves a political issue, the Court underlined that it has power to declare a law or executive action void. ${ }^{140}$ The Marbury v. Madison case thus establishes the power of the judiciary to invalidate the laws and executive actions for their unconstitutionality.

While the power to invalidate laws and executive actions for their unconstitutionality is upheld consistently, the approach which limits the power of courts when a constitutional case involves a political issue is not. The wellestablished precedent which is applicable now reveals that what matters is not whether a case involves a political issue or not, but whether the case can be decided by applying the constitution or laws in the country. The Administrative Procedure Act of 1946 and the judicial precedent have removed the constraint which existed earlier.

\section{Conclusion}

This article has explored the territorial or nation-state federal system of the US, the formally centralized quasi-federal system of India and the Ethiopian ethnic federal system from the perspectives of unity and protection of minority groups. It has highlighted that neither the US territorial federal system nor the purely ethnic federal arrangement followed by Ethiopia can be a solution for multicultural states like India and Ethiopia. A purely ethnic federal arrangement which ignores historical, economic and social factors in organizing political entities magnifies differences and leads to instability.

While the forces of unity should not impose undesired restrictions on diversity, the other extreme of establishing a purely ethnic federal system and giving excessive emphasis for ethnic diversity (as in the Ethiopian federal system) is also problematic as this would lead to conflicts. In a nutshell, neither individual liberalism nor communalism is a solution for most countries if the rights of all sections of the society are to be addressed. Once minority groups are identified, the rights given to them should accord them protection against despotism by the dominant group. However, minority rights should not be misconstrued to the extreme in such a manner that a minority group can destabilize a political system. ${ }^{141}$

Based on various literature and analysis, this article has also indicated the problems associated with the electoral systems and the manner of selection of members of the upper houses of the US, Ethiopia and India. Shared federal

\footnotetext{
${ }^{139} \mathrm{http}: / /$ www.lectlaw.com/def2/m079.htm

${ }^{140}$ Marbury Vs Madison, 5 U.S. 137, 1803.

${ }^{141}$ Supra note 17, p. 46.
} 
institutions are indispensable to work together on areas of common interest and that maintains a union in a federation. For shared federal institutions to be legitimate and effective, they have to accommodate diverse groups. One of the schemes that can accommodate regional or diverse interests through shared federal institutions is the establishment of a representative upper house. Each state in the US has two representatives in the Senate (upper house), and such equal representation of both small and larger states can be a safeguard against domination by the large ones. But, equal representation of states does not mean equal protection of diverse groups within each state as majority groups in each state can dominate minorities. This necessitates protection systems for regional minorities.

While both the US and Indian federal legislatures are bicameral composed of both lower and upper houses, the Ethiopian legal regime does not enable the upper house which represents diversity, i.e., House of Federation, to have any involvement in the law making process. Thus, the constitutional protection of diverse groups in Ethiopia can easily be paralyzed through the lawmaking role of the lower house which is dominated by a few ethnic groups. To be legitimate, a federal legislature has to incorporate both unity (through the lower house) and diversity through the upper house. Thus, the Ethiopian legislature needs reform. India's practice of setting a limit on the maximum number of seats for states or ethnic groups in the second chambers can be a feasible solution in Ethiopia to enable the minorities to collectively counterbalance the majorities in these federations.

This article has also identified some potential threats to unity in federal systems. Excessive asymmetry of power, failure to accommodate diversity, constitutionally proclaimed right to secession, ethnic federalism and absence of federal supremacy clause are among the major potential threats to a union in a federation. While asymmetrical treatment of non-state units in the US has ensured healthy functioning of the federation, asymmetrical treatment among the states in India has led to some conflicts. In Ethiopia too, an excessive asymmetry of power caused by the de facto single party system has posed serious challenges to the integrity of the country.

Finally, this article has briefly explored the constitutional umpiring institutions in the three jurisdictions. The discussion has shown that neither reliance solely on ordinary courts nor political institutions (such as the House of Federation) are feasible to determine constitutional disputes especially when a federal system is multicultural. Thus, constitutional disputes that involve fundamental individual rights can be adjudicated by ordinary courts and the establishment of a specialized court for the remaining disputes would be feasible to effectively address constitutional disputes. 